\title{
PENINGKATAN KEMAMPUAN PEMECAHAN MASALAH MATEMATIKA TERBUKA MELALUI PENDEKATAN INVESTIGASI BAGI MAHASISWA PRODI PENDIDIKAN MATEMATIKA FKIP UMSU PADA MATAKULIAH TEORI BILANGAN
}

\author{
Nur 'Afifah', Ismail Hanif Batubara² \\ ${ }^{1,2}$ Program Studi Pendidikan Matematika Universitas Muhammadiyah Sumatera Utara \\ ${ }^{1}$ nurafifah@umsu.ac.id
}

\begin{abstract}
The research objectives are: (1) Knowing whether the approach to the mathematical investigation can improve the ability to solve open mathematical problems; (2) Knowing how the level of activity of students and lecturers in learning through a mathematical investigation approach. This type of research is Class Action Research. The research subjects were Students of Mathematics Education FKIP UMSU Academic Year 2018/2019. The object of research is the ability of lecturers to manage student learning and activities in the implementation of learning and the ability of students to solve open mathematical problems through an investigative approach to material numbers. The results of the study show that (1) The approach to the mathematical investigation can improve students' mathematical problemsolving abilities; (2) The approach to the mathematical investigation can increase the level of student activity. From the results of the initial test the ability to solve open mathematical problems an average value of 3.17 , the average value of student cycle I tests is 10.73 (56.66\%) students who have the ability to solve open mathematical problems and average test scores the second cycle was 12 (83.33\%) students who had the ability to solve open mathematical problems. Based on the conclusions above, this study suggests that consider the application of a mathematical investigation approach in order to improve the quality of mathematics learning.
\end{abstract}

Keywords: Mathematical Investigation, Problem-Solving, Open-Mathematics.

\begin{abstract}
Abstrak. Tujuan penelitian adalah: (1) Mengetahui apakah pendekatan investigasi matematika dapat meningkatkan kemampuan pemecahan masalah matematika terbuka; (2) Mengetahui bagaimana kadar aktivitas mahasiswa dan dosen dalam pembelajaran melalui pendekatan investigasi matematika. Jenis penelitian adalah Penelitian Tindakan Kelas. Subyek penelitian adalah Mahasiswa Pendidikan Matematika FKIP UMSU Tahun Ajaran 2018/2019. Objek Penelitian adalah kemampuan dosen mengelola pembelajaran dan aktivitas mahasiswa dalam pelaksanaan pembelajaran serta kemampuan mahasiswa dalam pemecahan masalah matematika terbuka melalui pendekatan investigasi pada materi bilangan. Hasil penelitian menunjukkan bahwa (1) Pendekatan investigasi matematika dapat meningkatkan kemampuan pemecahan masalah matematika mahasiswa; (2) Pendekatan investigasi matematika dapat meningkatkan kadar aktivitas mahasiswa. Dari hasil tes awal kemampuan pemecahan masalah matematika terbuka nilai rata-rata sebesar 3,17, nilai rata-rata tes siklus I mahasiswa adalah $10,73(56,66 \%)$ mahasiswa yang memiliki kemampuan pemecahan masalah matematika terbuka dan rata-rata nilai tes siklus II adalah $12(83,33 \%)$ mahasiswa yang memiliki kemampuan pemecahan masalah matematika terbuka. Berdasarkan kesimpulan di atas maka penelitian ini menyarankan agar mempertimbangkan penerapan pendekatan investigasi matematika dalam rangka peningkatan kualitas pembelajaran matematika.
\end{abstract}

Kata Kunci: Investigasi Matematika, Pemecahan masalah, Matematika terbuka

\section{PENDAHULUAN}

National Council of Teacher Mathematic (NCTM, 2000) menetapkan ada 5 keterampilan proses yang harus dikuasai mahamahasiswa melalui pembelajaran matematika, yaitu: (1) pemecahan masalah (problem solving); (2) penalaran dan pembuktian (reasoning and proof); (3) koneksi (connection); (4) komunikasi (communication); serta (5) representasi (representation). Kelima keterampilan proses 
matematika ini harus dapat dikembangkan melalui pembelajaran matematika. Oleh karena itu, perlu dipertimbangkan untuk merancang pembelajaran matematika yang secara komprehensip dapat meningkatkan penguasaan fakta dan prosedur, pemahaman konsep serta penguasaan keterampilan proses matematika sekaligus. Salah satu permasalahan strategis yang dialami mahamahasiswa prodi pendidikan matematika FKIP UMSU pada matakuliah teori bilangan. Pada matakuliah teori bilangan mahamahasiswa prodi pendidikan matematika FKIP UMSU kurang mampu dalam pemecahan masalah matematika terbuka. Sehingga mahasiswa mengalami kesulitan dalam matakuliah teori bilangan. Akibatnya mahasiswa memandang matakuliah teori bilangan adalah matakuliah yang sulit dan membosankan. Salah satu masalahnya adalah: Buah mangga sebanyak 63 kantong (tiap kantong berisi sama banyak) dan 7 mangga di luar kantong, dibagi sama banyak kepada 23 orang. Berapa isi satu kantong dan banyak yang diterima setiap orang?

Hasilnya, ternyata dari 30 mahasiswa yang mengikuti tes awal, sebanyak 93,33\% (28 orang) dapat dikatakan kurang mampu menyelesaikan masalah matematika terbuka dengan baik. Ketidakmampuan mahasiswa menyelesaikan masalah seperti di atas dipengaruhi oleh kekurang-mampuannya menguasai konsep-konsep operasi hitung yang dibutuhkan untuk menyelesaikan masalah tersebut. Selanjutnya mahasiswa kurang mampu dalam memahami bahasa pada soal dan mahasiswa belajar sesuai dengan contoh yang diberikan, dan soalsoal yang diberikan kepada mahasiswa hanya soal-soal tertutup. Akibatnya, mahasiswa kurang berkesempatan untuk mengembangkan pemecahan masalah matematika terbuka.

Menurut Batubara (2017) matematika merupakan salah satu pembelajaran yang dipelajari di sekolah dan mempunyai peranan penting dalam kehidupan sehari-hari yang memiliki banyak cabang mulai dari aljabar, statistik, hingga kalkulus. Selanjutnya Batubara (2017) berpendapat bahwa Matematika dengan berbagai peranannya menjadikannya sebagai ilmu yang sangat penting, dan salah satu peranan matematika adalah sebagai alat berpikir untuk mengantarkan peserta didik memahami konsep matematika yang sedang dipelajarinya. Seseorang harus memiliki banyak pengalaman dalam memecahkan berbagai masalah, untuk memperoleh kemampuan dalam pemecahan masalah. Dalam hal ini, investigasi mendorong mahasiswa untuk belajar lebih aktif dan lebih bermakna, artinya mahasiswa dituntut selalu berfikir tentang suatu persoalan dan mereka mencari sendiri cara penyelesaiannya, dengan demikian mereka akan lebih terlatih untuk selalu menggunakan ketrampilan pengetahuaannya, sehingga pengetahuan dan pengalaman belajar mereka akan tertanam untuk jangka waktu yang cukup lama. Atas permasalahan tersebut, pembelajaran seharusnya lebih menekankan kepada aktivitas mahasiswa sebagai pusat pembelajaran. Mahasiswa didorong untuk aktif baik secara mental maupun fisik. Mahasiswa didorong untuk mampu mengembangkan pengetahuannya sendiri melalui bimbingan yang diberikan oleh dosen. Dalam pembelajaran matematika, mahasiswa harus dirangsang untuk mencari sendiri, melakukan penyelidikan sendiri (investigation), melakukan pembuktian terhadap suatu dugaan (conjecture) yang mereka buat sendiri, dan mencari tahu jawaban atas pertanyaan teman atau pertanyaan dosen (Turmudi, 2008).

Peneliti menerapkan pendekatan investigasi matematika untuk meningkatkan kemampuan mahasiswa prodi pendidikan matematika FKIP UMSU dalam memecahkan masalah matematika terbuka. Dengan pendekatan investigasi matematika, mahasiswa secara aktif mengkonstruksi atau merekonstruksi kembali pengetahuannya serta mampu mengaplikasikan dalam pemecahan masalah. Pada tahap ini, mahasiswa sudah memiliki potensi untuk berpikir kritis, kreatif, dan produktif. Potensi tersebut perlu dikembangkan melalui kegiatan investigasi, sehingga mahasiswa lebih diberikan kesempatan untuk memikirkan, mengembangkan, dan menyelidiki hal-hal menarik yang mengusik rasa keingintahuan mereka (Burns dalam Japa, 2008). Sesuai dengan pendapat Setiawan (Pusat Pengembangan dan Penata Dosen Matematika, 2006) langkah-langkah pendekatan 
investigasi yang diterapkan adalah (1) Fase membaca, menerjemahkan dan memahami masalah; (2) Fase pemecahan masalah; (3) Fase menjawab dan mengkomunikasikan jawaban.

Melalui tindakan investigasi, anak mengkonstruksi pengetahuannya secara aktif sehingga pemahaman dan hasil belajarnya meningkat. Hal ini didukung sebuah hasil penelitian yang menyatakan bahwa, dengan menerapkan investigasi matematika ternyata dalam belajar mahasiswa tampak aktif, kreatif, produktif, antusias, dan disiplin (Japa, 2008) dan dengan menerapkan investigasi matematika ternyata dapat menghilangkan miskonsepsi mahasiswa bahkan telah terjadi peningkatan pemahaman tentang materi yang dipelajarinya (Masrinawatie, 1999). Dalam melakukan investigasi, seorang mahasiswa harus mempunyai kemampuan mengenal dan mengerti bermacam bentuk informasi berkaitan dengan masalah matematika terbuka. Secara konseptual, masalah terbuka dalam matematika adalah masalah atau soal-soal matematika yang dirumuskan sedemikian rupa, sehingga memiliki beberapa atau bahkan banyak solusi yang benar dan terdapat banyak cara untuk mencapai solusi tersebut. Pembelajaran yang berdasarkan masalah matematika terbuka sangat sesuai dengan tuntutan KKNI. Di samping mengembangkan kemampuan pemecahan masalah (problem solving), metode ini juga menekankan pada pencapaian kompetensi matematis tingkat tinggi yaitu berpikir kritis, kreatif dan produktif.

\section{METODE}

Penelitian ini merupakan penelitian tindakan kelas. Penelitian tindakan dirancang dengan proses pengkajian berdaur (cyclical) yang terdiri dari permasalahan, alternatif pemecahan (Rencana Tindakan), pelaksanaan tindakan, observasi, analisis data dan refleksi (Tim Pelatih Proyek PGSM, 1999). Penelitian tindakan kelas ini dilakukan berupa kegiatan pengajaran dengan materi pelajaran bilangan, dimana peneliti sendiri terlibat sebagai pengajar di kelas. Adapun desain penelitian tindakan keLembar Aktivitas Siswa ini dilakukan sesuai dengan skema berikut:

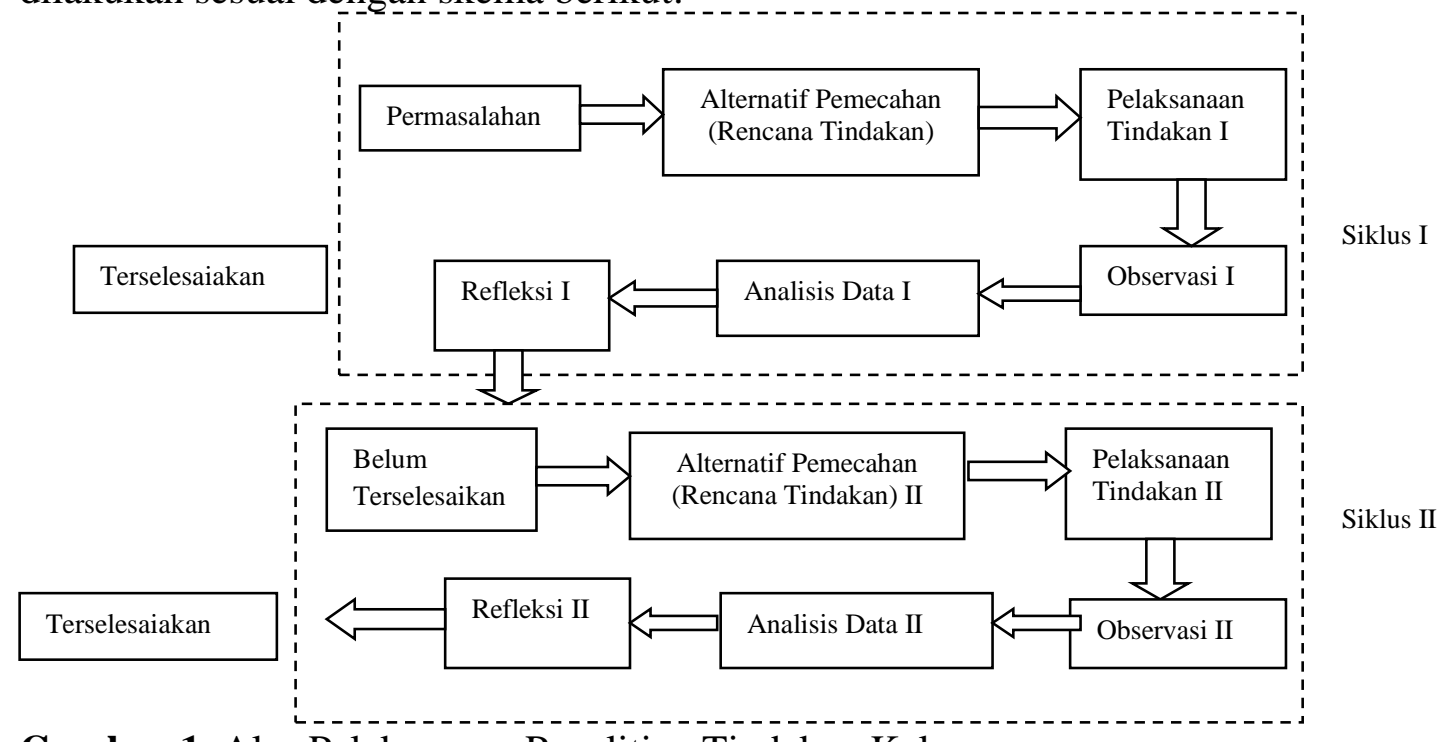

Gambar 1. Alur Pelaksanaan Penelitian Tindakan Kelas

\section{HASIL DAN PEMBAHASAN \\ Hasil}

Data penelitian yang diperoleh merupakan data observasi hasil pengamatan terhadap aktivitas dosen, aktivitas mahasiswa dan kemampuan pemecahan masalah matematika terbuka mahasiswa. Untuk menyajikan data hasil pelaksanaan penelitian, berikut disampaikan secara berurutan sesuai siklusnya. 


\section{Deskripsi Siklus I}

a. Pelaksanaan Tindakan

Kegiatan yang dilakukan pada kegiatan inti adalah dosen menyajikan masalah seperti yang tertera pada lembar aktivitas Mahasiswa 1. Selanjutnya membimbing mahasiswa membaca, memahami dan memecahkan masalah, mengarahkan mahasiswa untuk menginterpretasikan soal berdasarkan pengertiannya dan menerjemahkan ke dalam bahasa matematika serta membuat kesimpulan tentang apa yang harus dikerjakannya, misalnya membuat apa yang diketahui, ditanya dan penyelesaiannya. Dalam hal ini, mahasiswa bekerja secara individu. Memberikan kesempatan kepada mahasiswa mengerjakan soal sesuai ide mereka sendiri yang mereka dapatkan dan memberikan saran dan membimbing mahasiswa untuk memulai pemecahan dengan suatu cara/ strategi, misalnya dengan membuat peragaan dengan maksud untuk memberi tantangan atau menggali pengetahuan mahasiswa sehingga mereka terangsang untuk mencoba mencari cara-cara yang mungkin untuk digunakan dalam pemecahan soal tersebut. Menyuruh mahasiswa mencek kembali penyelesaian yang diperoleh sehingga yakin akan kebenarannya.

Berikut ini, disajikan satu contoh mewakili pekerjaan mahasiswa pada lembar aktivitas mahasiswa untuk masalah 1:

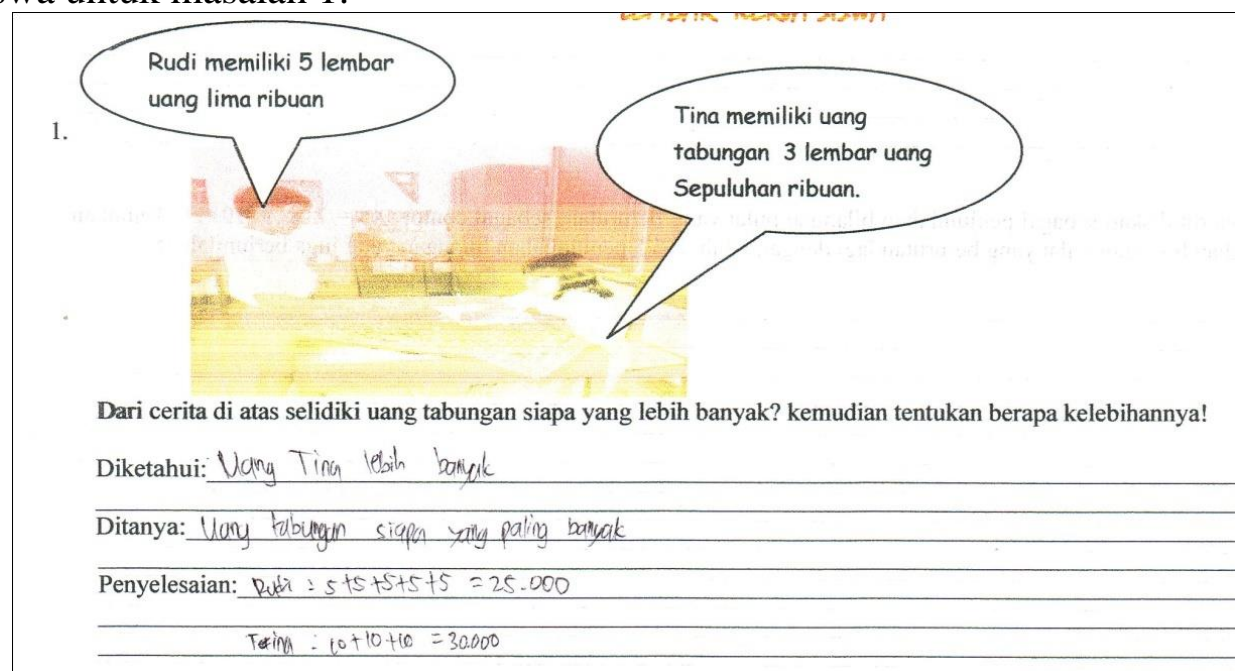

Gambar 2. Gambaran Proses Jawaban Mahasiswa dalam Meneyelesaikan Masalah

Pekerjaan Mahasiswa di atas, tampak bahwa mahasiswa memahami apa yang diketahui dan apa yang ditanya. Dalam hal ini, mahasiswa berusaha menyelesaikan masalah dengan melakukan operasi penjumlahan akan tetapi mahasiswa belum dapat menjawab dari apa yang ditanya. Jadi dapat disimpulkan, mahasiswa tersebut telah melakukan karakteristik dari pendekatan investigasi. Secara kuantitatif, tingkat kemampuan mahasiswa memecahkan masalah matematika terbuka pada Tes Kemampuan Masalah Matematika Terbuka (TKPMMT I) dapat dilihat pada tabel berikut ini:

Tabel 1. Kemampuan Pemecahan Masalah Matematika Terbuka pada Siklus I

\begin{tabular}{ccccc}
\hline No & $\begin{array}{c}\text { Interval tingkat } \\
\text { Penguasaan }\end{array}$ & Jumlah & Persentase (\%) & Kategori Penilaian \\
\hline 1 & $85-100$ & 2 & 6,67 & Sangat baik \\
\hline 2 & $70-84$ & 2 & 6,67 & Baik \\
\hline 3 & $55-69$ & 13 & 43.33 & Cukup baik \\
\hline 4 & $40-54$ & 8 & 26,66 & Kurang baik \\
\hline 5 & $0-39$ & 5 & 16,67 & Sangat kurang \\
\hline & Total & 30 & 100 & \\
\hline
\end{tabular}


Tingkat kemampuan mahasiswa memecahkan masalah pada tes kemampuan pemecahan masalah matematika terbuka (TKPMMT I) masih tergolong kurang baik, dengan nilai rata-rata 10,37. Terdapat 2 orang yang memiliki kemampuan sangat baik, 2 orang yang memiliki kemampuan baik, 13 orang yang memiliki kemampuan cukup, 8 orang yang memiliki kemampuan kurang baik dan 5 orang yang memiliki kemampuan sangat kurang.

Dilihat dari secara keseluruhan tingkat kemampuan pemecahan masalah matematika terbuka mahasiswa yang mencapai kriteria minimal cukup adalah 17 orang dari 30 orang mahasiswa yang mengikuti tes kemampuan pemecahan masalah, atau 56,66\% dari seluruh jumlah mahasiswa yang mengikuti TKPMMT. Tingkat kemampuan pemecahan masalah yang direncanakan dalam penelitian $\geq 80 \%$ dari jumlah mahasiswa yang mengikuti tes. Untuk mencapai tingkat kemampuan pemecahan masalah yang direncanakan yaitu minimal $80 \%$, maka terdapat minimal $23,34 \%$ dari jumlah mahasiswa yang mengikuti tes sebagai kekurangannya. Hal ini akan menjadi perhatian sebagai bahan refleksi untuk tindak lanjut ke siklus II. Untuk lebih jelasnya dapat dicermati gambar tingkat kemampuan pemecahan masalah matematika terbuka berikut:

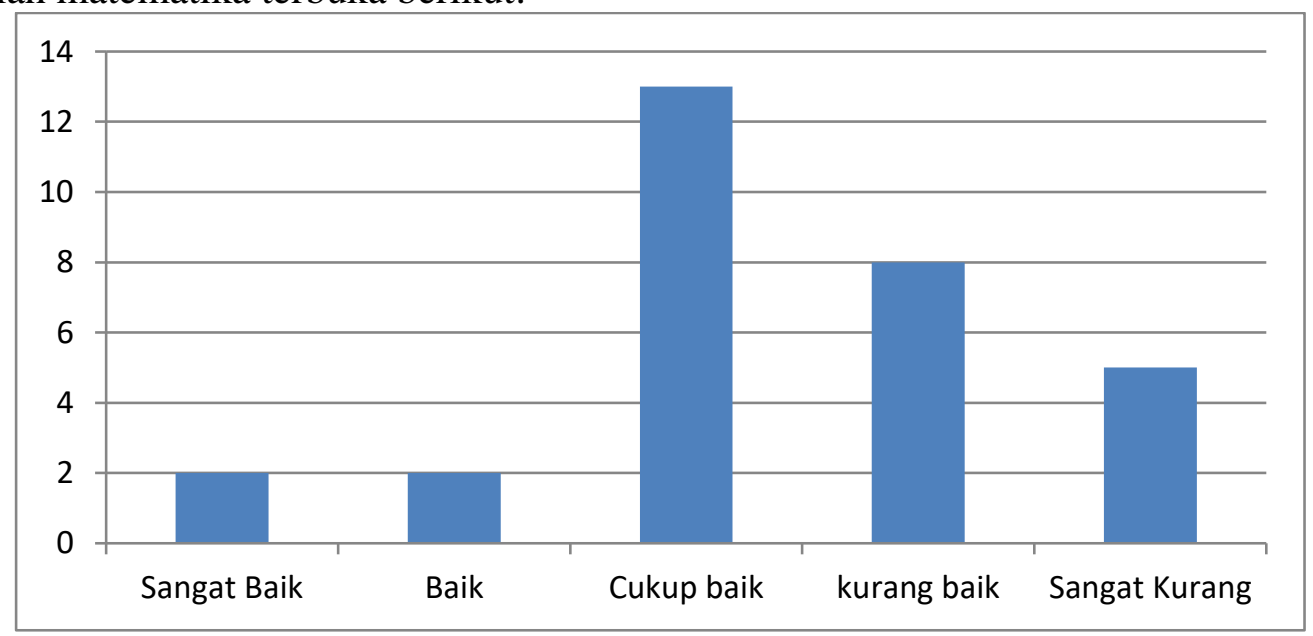

Gambar 3. Tingkat Kemampuan Pemecahan Masalah Matematika Terbuka

Berdasarkan gambar di atas, dapat dijelaskan bahwa untuk kategori penilaian "sangat tinggi" terdapat peningkatan kemampuan pemecahan masalah matematika terbuka dibandingkan dengan hasil pretes terdahulu, yaitu dari 1 menjadi 2 orang mahasiswa. Selanjutnya untuk kategori penilaian "baik" terdapat peningkatan yaitu dari 1 menjadi 2 orang mahasiswa.

\section{b. Pengamatan}

Pengamatan terhadap hasil tes kemampuan pemecahan masalah matematika terbuka setelah siklus I dapat dillihat dari hasil kerja mahasiswa dalam menyelesaikan tes yang diberikan Hasil tes mahasiswa umumnya masih rendah dilihat dari skor yang diperoleh. Masih ada mahasiswa yang memperoleh skor 5 dari skor maksimum 20. Dari 30 mahasiswa masih ada 13 mahasiswa yang belum mencapai kategori minimal cukup baik. Dari tes yang diberikan mahasiswa umumnya masih melakukan kesalahan dalam menyelesaikan soal. Berikut adalah hasil pengumpulan data dari instrumen observasi kegiatan mahasiswa dan kegiatan dsoen:

1. Hasil Observasi Aktivitas Mahasiswa

Selama kegiatan pelaksanaan siklus I yang terdiri dari 5 kali pertemuan, yaitu 4 kali pertemuan untuk proses pembelajaran dan 1 kali pertemuan untuk tes siklus I. Sepanjang proses pembelajaran, observer melakukan pengamatan pada setiap 
pertemuan pada siklus I. Observer melakukan pengamatan terhadap dosen dan mahasiswa. Berikut hasil pengamatan terhadap aktivitas mahasiswa pada siklus I:

Tabel 2. Kadar Aktivitas Mahasiswa Sikus I

\begin{tabular}{clcccc}
\hline \multirow{2}{*}{ No. Indikator } & \multicolumn{4}{c}{ Pertemua ke- } \\
\cline { 3 - 6 } & \multicolumn{1}{c}{ I } & II & III & IV \\
\hline 1 & $\begin{array}{l}\text { Mahasiswa menginterpretasikan soal berdasarkan } \\
\text { pengertiannya. }\end{array}$ & 1 & 3 & 4 & 3 \\
\hline 2 & $\begin{array}{l}\text { Mahasiswa mengerjakan soal sesuai ide mereka yang } \\
\text { mereka dapatkan secara mandiri atau kelompok } \\
\text { (bersama-sama) }\end{array}$ & 2 & 3 & 4 & 4 \\
\hline 3 & $\begin{array}{l}\text { Mahasiswa memulai pemecahan dengan suatu cara/ } \\
\text { strategi }\end{array}$ & 2 & 2 & 3 & 4 \\
\hline 4 & $\begin{array}{l}\text { Mahasiswa mencek kembali penyelesaian yang } \\
\text { diperoleh sehingga yakin akan kebenarannya }\end{array}$ & 1 & 2 & 3 & 4 \\
\hline 5 & $\begin{array}{l}\text { Mahasiswa mempresentasikan hasil yang diperoleh } \\
\text { dan mahasiswa yang lain memperhatikan }\end{array}$ & 2 & 3 & 4 & 5 \\
\hline \multicolumn{1}{c}{ Jumlah } & $\mathbf{8}$ & $\mathbf{1 3}$ & $\mathbf{1 8}$ & $\mathbf{2 0}$ \\
\hline & $\mathbf{3 2 \%}$ & $\mathbf{5 2 \%}$ & $\mathbf{7 2 \%}$ & $\mathbf{8 0 \%}$ \\
\hline
\end{tabular}

Berdasarkan informasi pada tabel di atas dapat diketahui bahwa selama proses pembelajaran pada pendekatan investigasi matematika pada pertemuan I diperoleh persentase $32 \%$ termasuk dalam kategori sangat kurang dan kriteria aktivitas mahasiswa pada pertemuan II diperoleh persentase $52 \%$ termasuk dalam kategori sangat kurang, sedangkan kriteria aktivitas mahasiswa pada pertemuan III dan IV diperoleh persentase 72 $\%$ dan $80 \%$ termasuk dalam kategori baik. Untuk secara keseluruhan, rerata persentase aktivitas mahasiswa yang berlangsung pada pertemuan pertama hingga sampai pertemuan keempat adalah 59\%. Sehingga dapat disimpulkan aktivitas mahasiswa mencapai tingkat kategori "sangat kurang".

Berdasarkan dari hasil persentase yang diperoleh pada pertemuan I yang masuk pada kriteria sangat kurang hal ini disebabkan pada awal pertemuan mahasiswa belum mampu menginterprestasikan soal berdasarkan pengertiannya dan kurang mampu memecahkan masalah matematika terbuka. Tetapi pada pertemuan kedua, ketiga dan keempat mahasiswa mulai menunjukkan aktivitas yang lebih baik untuk aspek menginterprestasikan soal, karena dosen lebih melakukan pendekatan dan lebih memotivasi mahasiswa pada pertemuan-pertemuan berikutnya.

2. Hasil Observasi Aktivitas Dosen

Sama halnya seperti pengamatan yang dilakukan terhadap mahasiswa, pengamatan terhadap aktivitas dosen dilakukan oleh observer dan dilakukan pada setiap pertemuan sepanjang proses pembelajaran berlangsung. Hasil pengamatan yang dilakukan observer dapat dilihat sebagai berikut:

Tabel 3. Kemampuan Dosen Mengelola Pembelajaran Siklus I

\begin{tabular}{clllll}
\hline \multirow{2}{*}{ No } & \multicolumn{1}{c}{ Aspek Yang Dinilai } & \multicolumn{4}{c}{ Pertemuan ke- } \\
\cline { 2 - 6 } & \multicolumn{1}{c}{ I } & II & III & IV \\
\hline 1 & & & & \\
\cline { 2 - 6 } & Pendahuluan & 4 & 4 & 5 & 5 \\
\cline { 2 - 6 } & $\begin{array}{l}\text { Mempucapkan salam } \\
\text { mahasiswa }\end{array}$ & 4 & 4 & 4 \\
\cline { 2 - 5 } & $\begin{array}{l}\text { Menyampaikan tujuan pembelajaran dan } \\
\text { memotivasi mahasiswa }\end{array}$ & 3 & 3 & 3 & 4 \\
\hline
\end{tabular}


Peningkatan kemampuan pemecahan masalah matematika terbuka...

\section{$2 \quad$ Kegiatan Inti}

\begin{tabular}{|c|c|c|c|c|}
\hline $\begin{array}{l}\text { Menyajikan materi pelajaran dengan } \\
\text { masalah }\end{array}$ & 3 & 4 & 5 & 5 \\
\hline $\begin{array}{l}\text { Membimbing mahasiswa membaca, } \\
\text { memahami dan memecahkan masalah }\end{array}$ & 3 & 3 & 4 & 5 \\
\hline $\begin{array}{l}\text { Mengarahkan mahasiswa untuk } \\
\text { menginterpretasikan soal (diketahui, } \\
\text { ditanya dan penyelesaiannya) }\end{array}$ & 3 & 4 & 5 & 4 \\
\hline $\begin{array}{l}\text { Memberikan kesempatan kepada } \\
\text { mahasiswa untuk mengerjakan soal sesuai } \\
\text { ide mereka sendiri }\end{array}$ & 4 & 4 & 4 & 4 \\
\hline $\begin{array}{l}\text { Memberikan saran dan membimbing } \\
\text { mahasiswa untuk memulai pemecahan } \\
\text { masalah dengan suatu cara/strategi }\end{array}$ & 3 & 3 & 5 & 3 \\
\hline $\begin{array}{l}\text { Mengarahkan mahasiswa untuk memilih } \\
\text { strategi yang tepat }\end{array}$ & 3 & 3 & 3 & 3 \\
\hline $\begin{array}{l}\text { Menyuruh mahasiswa untuk mencek } \\
\text { kembali penyelesaian yang diperoleh } \\
\text { sehingga yakin akan kebenarannya }\end{array}$ & 3 & 2 & 2 & 3 \\
\hline $\begin{array}{l}\text { Menyuruh beberapa mahasiswa } \\
\text { mempresentasikan hasil yang diperoleh }\end{array}$ & 4 & 4 & 3 & 4 \\
\hline $\begin{array}{l}\text { Memberikan kesempatan kepada } \\
\text { mahasiswa lain untuk bertanya }\end{array}$ & 3 & 3 & 3 & 4 \\
\hline $\begin{array}{l}\text { Mengambil kesimpulan tentang jawaban } \\
\text { yang didapat mahasiswa }\end{array}$ & 3 & 2 & 3 & 3 \\
\hline Menyajikan masalah yang kedua & 3 & 3 & 4 & 3 \\
\hline $\begin{array}{l}\text { Memberikan kesempatan kepda } \\
\text { mahasiswa untuk mencari pemecahan } \\
\text { masalah kedua }\end{array}$ & 3 & 3 & 3 & 3 \\
\hline $\begin{array}{l}\text { Mempresentasikan hasil yang diperoleh } \\
\text { mahasiswa }\end{array}$ & 2 & 4 & 3 & 5 \\
\hline $\begin{array}{l}\text { Bersama dengan mahasiswa mengerjakan } \\
\text { pemecahan masalah yang kedua }\end{array}$ & 3 & 5 & 4 & 3 \\
\hline \multicolumn{5}{|l|}{ Penutup } \\
\hline $\begin{array}{l}\text { Memberi penilaian terhadap hasil belajar } \\
\text { masing-masing mahasiswa }\end{array}$ & 3 & 4 & 3 & 3 \\
\hline $\begin{array}{l}\text { Menutup pelajaran dan membuat } \\
\text { kesimpulan bersama mahasiswa }\end{array}$ & 3 & 4 & 3 & 3 \\
\hline Jumlah & 60 & 66 & 69 & 71 \\
\hline Persentase & $63.16 \%$ & $69.47 \%$ & $72.63 \%$ & $74.74 \%$ \\
\hline
\end{tabular}

Berdasarkan kriteria kemampuan dosen mengelola pembelajaran, maka dengan melihat data pada tabel dapat disimpulkan bahwa, nilai rata-rata per pertemuan kemampuan dosen mengelola pembelajaran pada pertemuan pertama sampai pertemuan kedua mencapai tingkat kategori "kurang baik". Pada pertemuan ketiga sampai keempat nila rataratanya mencapai tingkat kategori "cukup baik". Untuk secara keseluruhan, rerata persentase pengelolahan pembelajaran yang berlangsung pada pertemuan pertama hingga sampai pertemuan keempat dapat disimpulkan dosen mengelola pembelajaran mencapai tingkat kategori "cukup baik". 


\section{c. Refleksi Siklus I}

Refleksi ini dilakukan bersama dengan pengamat. Refleksi yang dilakukan merupakan refleksi hasil tindakan terhadap: (1) kemampuan mahasiswa memecahkan masalah matematika terbuka pada hasil tes siklus I (2) refleksi terhadap aktivitas mahasiswa selama proses pembelajaran; (3) refleksi terhadap dosen dalam mengelola pembelajaran;

\section{Deskripsi Siklus II}

a. Pelaksanaan Tindakan

Kegiatan yang dilakukan pada kegiatan inti adalah dosen menyajikan masalah seperti yang tertera pada lembar aktivitas mahasiswa 3. Selanjutnya membimbing mahasiswa membaca, memahami dan memecahkan masalah, mengarahkan kelompok mahasiswa untuk menginterpretasikan soal berdasarkan pengertiannya dan menerjemahkan ke dalam bahasa matematika serta membuat kesimpulan tentang apa yang harus dikerjakannya, misalnya membuat apa yang diketahui, ditanya dan penyelesaiannya. Memberikan kesempatan kepada kelompok mahasiswa mengerjakan soal sesuai ide mereka dan memberikan saran dan membimbing kelompok mahasiswa untuk memulai pemecahan dengan suatu cara/ strategi, misalnya dengan membuat peragaan dengan maksud untuk memberi tantangan atau menggali pengetahuan mahasiswa sehingga mereka terangsang untuk mencoba mencari cara-cara yang mungkin untuk digunakan dalam pemecahan soal tersebut. Menyuruh kelompok mahasiswa mencek kembali penyelesaian yang diperoleh sehingga yakin akan kebenarannya.

Secara kuantitatif, tingkat kemampuan mahasiswa memecahkan masalah matematika terbuka pada tes kemampuan pemecahan masalah (TKPMMT II) dapat dilihat pada tabel berikut ini:

Tabel 4. Kemampuan Pemecahan Masalah Matematika Terbuka pada Siklus II

\begin{tabular}{ccccc}
\hline No & $\begin{array}{c}\text { Interval tingkat } \\
\text { Penguasaan }\end{array}$ & Jumlah & Persentase (\%) & Kategori Penilaian \\
\hline 1 & $85-100$ & 3 & 10,00 & Sangat baik \\
\hline 2 & $70-84$ & 1 & 3,33 & Baik \\
\hline 3 & $55-69$ & 21 & 70,00 & Cukup baik \\
\hline 4 & $40-54$ & 4 & 13,34 & Kurang baik \\
\hline 5 & $0-39$ & 1 & 3,33 & Sangat kurang \\
\hline & Total & 30 & 100 & \\
\hline
\end{tabular}

Tingkat kemampuan mahasiswa memecahkan masalah pada tes kemampuan pemecahan masalah matematika terbuka (TKPMMT II) adalah cukup baik, dengan nilai rata-rata 12 . Terdapat 3 orang yang memiliki kemampuan sangat baik, 1 orang yang memiliki kemampuan baik, 21 orang yang memiliki kemampuan cukup, 4 orang yang memiliki kemampuan kurang baik dan 1 orang yang memiliki kemampuan sangat kurang.

Dilihat dari hasil tes kemampuan pemecahan masalah matematika terbuka secara keseluruhan, tingkat kemampuan mahasiswa yang mencapai kriteria minimal cukup adalah 25 orang dari 30 orang mahasiswa yang mengikuti tes kemampuan pemecahan masalah, atau $83,33 \%$ dari seluruh jumlah mahasiswa yang mengikuti TKPMMT. Tingkat kemampuan pemecahan masalah yang direncanakan dalam penelitian $\geq 80 \%$ dari jumlah mahasiswa yang mengikuti tes. Secara klasikal tingkat kemampuan pemecahan masalah matematika terbuka mahasiswa telah memenuhi tingkat kemampuan pemecahan masalah yang direncanaka. Jadi penelitian berhenti pada siklus II. Untuk lebih jelasnya dapat dicermati gambar tingkat kemampuan pemecahan masalah matematika terbuka berikut: 
Peningkatan kemampuan pemecahan masalah matematika terbuka...

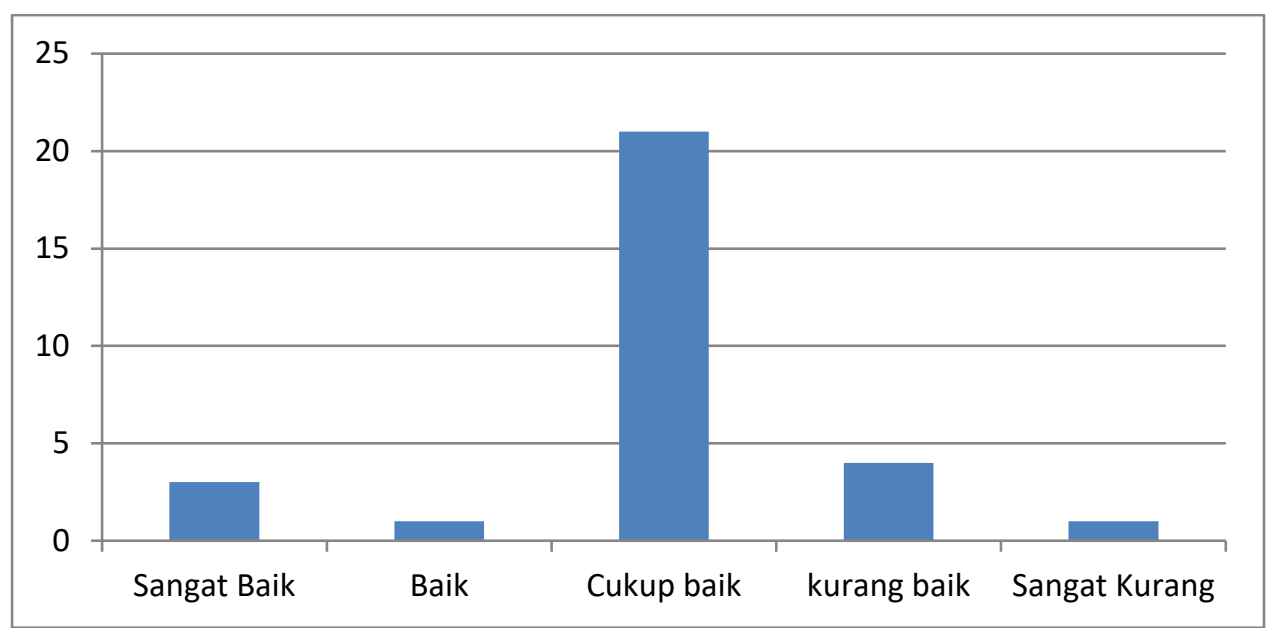

Gambar 4. Tingkat Kemampuan Pemecahan Masalah Matematika Terbuka

Berdasarkan gambar di atas, dapat dijelaskan bahwa untuk kategori penilaian "sangat tinggi" terdapat peningkatan kemampuan pemecahan masalah matematika terbuka dibandingkan dengan hasil tes kemampuan pemecahan masalah matematika terbuka pada siklus I, yaitu dari 2 menjadi 3 orang mahasiswa. Selanjutnya untuk kategori penilaian "baik" terdapat penurunan yaitu dari 2 menjadi 1 orang mahasiswa. Hal ini disebabkan salah satu siswa yang berada pada kategori "baik" pada tes kemampuan pemecahan masalah matematika terbuka siklus 1 mengalami kenaikan menjadi kategori penilaian "sangat baik".

Kategori "cukup baik" terdapat peningkatan dari 13 menjadi 21 orang mahasiswa. Kategori "kurang baik" terdapat penurunan dari 8 menjadi 4 orang mahasiswa. Hal ini merupakan penurunan yang sangat diharapkan, karena kemampuan pemecahan masalah matematika terbuka mahasiswa meningkat. Dan untuk kategoi "sangat kurang" terdapat penurunan dari 5 menjadi 1 orang mahasiswa, hal ini menggambarkan bahwa tingkat kemampuan pemecahan masalah matematika terbuka mahasiswa meningkat.

Secara klasikal terdapat peningkatan kemampuan pemecahan masalah matematika terbuka mahasiswa pada siklus I yaitu dari 56,66\% menjadi $83,33 \%$. Peningkatan tersebut signifikan, karena telah mencapai tingkat kemampuan pemecahan masalah yang direncanakan yaitu $\geq 80 \%$. Penelitian ini berhenti pada siklus II bila ditinjau dari segi peningkatan kemampuan pemecahan masalah matematika terbuka.

b. Pengamatan

Hasil pengamatan aktivitas mahasiswa pada saat proses pembelajaran selama siklus II berlansung, secara umum sudah baik. Pada umumnya setiap mahasiswa sudah menunjukkan adanya kemunculan setiap aspek aktivitas selama kegiatan pembelajaran berlangsung. Aktivitas terhadap pembelajaran pada siklus II. Berikut adalah hasil pengumpulan data dari instrumen observasi kegiatan mahasiswa dan kegiatan dosen:

1) Hasil Observasi Aktivitas Mahasiswa

Selama kegiatan pelaksanaan siklus II yang terdiri dari 5 kali pertemuan, yaitu 4 kali pertemuan untuk proses pembelajaran dan 1 kali pertemuan untuk tes siklus II. Sepanjang proses pembelajaran, observer melakukan pengamatan pada setiap pertemuan pada siklus II. Observer melakukan pengamatan terhadap dosen dan mahasiswa. Berikut hasil pengamatan terhadap kadar aktivitas siswa pada siklus II: 
Tabel 5. Kadar Aktivitas Mahasiswa Siklus II

\begin{tabular}{|c|c|c|c|c|c|}
\hline \multirow{2}{*}{ No. } & \multirow{2}{*}{ Indikator } & \multicolumn{4}{|c|}{ Pertemua ke- } \\
\hline & & $\mathbf{I}$ & II & III & IV \\
\hline 1 & $\begin{array}{l}\text { Mahasiswa } \\
\text { menginterpretasikan soal } \\
\text { berdasarkan pengertiannya. }\end{array}$ & 3 & 5 & 4 & 4 \\
\hline 2 & $\begin{array}{l}\text { Mahasiswa mengerjakan soal } \\
\text { sesuai ide mereka yang mereka } \\
\text { dapatkan secara mandiri atau } \\
\text { kelompok (bersama-sama) }\end{array}$ & 3 & 3 & 5 & 5 \\
\hline 3 & $\begin{array}{l}\text { Mahasiswa memulai } \\
\text { pemecahan dengan suatu cara/ } \\
\text { strategi }\end{array}$ & 3 & 4 & 5 & 4 \\
\hline 4 & $\begin{array}{llr}\text { Mahasiswa } & \text { mencek } & \text { kembali } \\
\text { penyelesaian } & \text { yang } & \text { diperoleh } \\
\text { sehingga } & \text { yakin } & \text { akan } \\
\text { kebenarannya } & & \\
\end{array}$ & 3 & 4 & 4 & 5 \\
\hline 5 & 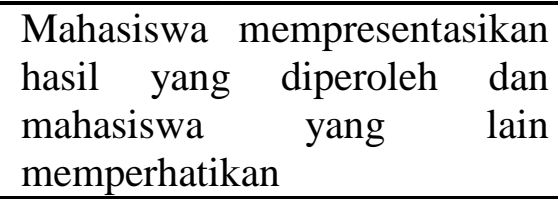 & 4 & 3 & 4 & 5 \\
\hline & Jumlah & 16 & 19 & 22 & 23 \\
\hline & Persentase Rata-rata Skor & $64 \%$ & $76 \%$ & $88 \%$ & $92 \%$ \\
\hline & Keterangan & Kurang baik & Cukup baik & baik & Sangat baik \\
\hline
\end{tabular}

Berdasarkan informasi pada tabel di atas dapat diketahui bahwa selama proses pembelajaran pada pendekatan investigasi matematika pada pertemuan I diperoleh persentase $64 \%$ termasuk dalam kategori kurang baik dan kriteria aktivitas mahasiswa pada pertemuan II diperoleh persentase $76 \%$ termasuk dalam kategori cukup baik, pada pertemuan III diperoleh persentase $88 \%$ termasuk dalam kategori baik dan untuk pertemuan IV diperoleh persentase $92 \%$ termasuk dalam kategori sangat baik.

Sehingga dari persentase aktivitas mahasiswa secara keseluruhan dari siklus II yaitu dari pertemuan I hingga pertemuan IV, disimpulkan bahwa siswa mencapai semua indikator yang diukur dengan penilaian yang baik. Hal ini dapat dilihat dari rerata persentase skor pada pertemuan I sampai pertemuan IV.

2) Hasil Observasi Aktivitas Dosen

Berdasarkan hasil pengamatan pengelolaan pembelajaran pendekatan investigasi matematika siklus II disajikan dalam tabel berikut ini:

Tabel 6. Kemampuan Dosen Mengelola Pembelajaran Siklus II

\begin{tabular}{clllll}
\hline \multirow{2}{*}{ No } & \multicolumn{1}{c}{ Aspek Yang Dinilai } & \multicolumn{4}{c}{ Pertemuan ke- } \\
\cline { 2 - 6 } 1 & Pendahuluan & I & II & III & IV \\
\cline { 2 - 6 } & Mengucapkan salam & 4 & 5 & 5 & 5 \\
\cline { 2 - 6 } & $\begin{array}{l}\text { Mempersiapkan kondisi belajar } \\
\text { mahasiswa }\end{array}$ & 5 & 3 & 4 & 5 \\
\cline { 2 - 6 } & $\begin{array}{l}\text { Menyampaikan tujuan } \\
\text { pembelajaran dan memotivasi } \\
\text { mahasiswa }\end{array}$ & 4 & 5 & 4 & 4 \\
& & & & \\
\end{tabular}


Peningkatan kemampuan pemecahan masalah matematika terbuka...

\begin{tabular}{|c|c|c|c|c|c|}
\hline \multirow[t]{15}{*}{2} & \multicolumn{5}{|l|}{ Kegiatan Inti } \\
\hline & $\begin{array}{l}\text { Menyajikan materi pelajaran } \\
\text { dengan masalah }\end{array}$ & 4 & 5 & 4 & 5 \\
\hline & $\begin{array}{l}\text { Membimbing mahasiswa } \\
\text { membaca, memahami dan } \\
\text { memecahkan masalah }\end{array}$ & 3 & 4 & 5 & 5 \\
\hline & $\begin{array}{l}\text { Mengarahkan mahasiswa untuk } \\
\text { menginterpretasikan soal } \\
\text { (diketahui, ditanya dan } \\
\text { penyelesaiannya) }\end{array}$ & 4 & 4 & 5 & 5 \\
\hline & $\begin{array}{l}\text { Memberikan kesempatan kepada } \\
\text { mahasiswa untuk mengerjakan } \\
\text { soal sesuai ide mereka sendiri }\end{array}$ & 3 & 4 & 4 & 5 \\
\hline & $\begin{array}{l}\text { Memberikan saran dan } \\
\text { membimbing mahasiswa untuk } \\
\text { memulai pemecahan masalah } \\
\text { dengan suatu cara/strategi }\end{array}$ & 3 & 3 & 4 & 5 \\
\hline & $\begin{array}{l}\text { Mengarahkan mahasiswa untuk } \\
\text { memilih strategi yang tepat }\end{array}$ & 3 & 4 & 4 & 5 \\
\hline & $\begin{array}{l}\text { Menyuruh mahasiswa untuk } \\
\text { mencek kembali penyelesaian } \\
\text { yang diperoleh sehingga yakin } \\
\text { akan kebenarannya }\end{array}$ & 3 & 3 & 4 & 4 \\
\hline & $\begin{array}{l}\text { Menyuruh beberapa mahasiswa } \\
\text { mempresentasikan hasil yang } \\
\text { diperoleh }\end{array}$ & 4 & 5 & 3 & 5 \\
\hline & $\begin{array}{l}\text { Memberikan kesempatan kepada } \\
\text { mahasiswa lain untuk bertanya }\end{array}$ & 3 & 4 & 4 & 4 \\
\hline & $\begin{array}{l}\text { Mengambil kesimpulan tentang } \\
\text { jawaban yang didapat mahasiswa }\end{array}$ & 3 & 3 & 3 & 5 \\
\hline & Menyajikan masalah yang kedua & 4 & 4 & 4 & 5 \\
\hline & $\begin{array}{l}\text { Memberikan kesempatan kepda } \\
\text { mahasiswa untuk mencari } \\
\text { pemecahan masalah kedua }\end{array}$ & 3 & 4 & 4 & 3 \\
\hline & $\begin{array}{l}\text { Mempresentasikan hasil yang } \\
\text { diperoleh mahasiswa }\end{array}$ & 3 & 4 & 3 & 3 \\
\hline & $\begin{array}{l}\text { Bersama dengan mahasiswa } \\
\text { mengerjakan pemecahan masalah } \\
\text { yang kedua }\end{array}$ & 3 & 4 & 4 & 5 \\
\hline \multirow[t]{6}{*}{3} & Penutup & & & & \\
\hline & $\begin{array}{l}\text { Memberi penilaian terhadap hasil } \\
\text { belajar masing-masing mahasiswa }\end{array}$ & 5 & 4 & 5 & 5 \\
\hline & $\begin{array}{l}\text { Menutup pelajaran dan membuat } \\
\text { kesimpulan bersama mahasiswa }\end{array}$ & 3 & 5 & 5 & 4 \\
\hline & Jumlah & 67 & 77 & 78 & 87 \\
\hline & Persentase & $70.53 \%$ & $81.05 \%$ & $82.11 \%$ & $91.58 \%$ \\
\hline & Keterangan & Cukup Baik & Baik & Baik & Sangat Baik \\
\hline
\end{tabular}


Berdasarkan kriteria kemampuan dosen mengelola pembelajaran, maka dengan melihat data pada tabel dapat disimpulkan bahwa, nilai rata-rata per pertemuan kemampuan dosen mengelola pembelajaran pada pertemuan pertama mencapai tingkat kategori "cukup baik". Pada pertemuan kedua dan ketiga mencapai tingkat kategori "baik". Sedangkan pada pertemuan keempat mencapai tingkat kategori "sangat baik". Untuk secara keseluruhan, rerata persentase pengelolahan pembelajaran yang berlangsung pada pertemuan pertama hingga sampai pertemuan keempat dapat disimpulkan dosen mengelola pembelajaran mencapai tingkat kategori "sangat baik".

c. Hasil Refleksi Pada Siklus II

Refleksi yang dilakukan merupakan refleksi hasil tindakan terhadap: (1) kemampuan mahasiswa memecahkan masalah matematika terbuka pada hasil tes siklus II; (2) refleksi terhadap aktivitas mahasiswa selama proses pembelajaran; (3) refleksi terhadap peneiliti dan anggota peneliti dalam mengelola model pembelajaran.

\section{Pembahasan}

Secara umum, pertanyaan penelitian yang ingin dijawab dalam penelitian ini ada 2, yaitu: (1) Apakah terdapat peningkatan kemampuan pemecahan masalah matematika terbuka melalui pendekatan investigasi matematika, dan (2) Bagaimana peningkatan kadar aktifitas siswa dalam pembelajaran melalui pendekatan investigasi matematika. Deskripsi dan interpretasi data hasil penelitian terhadap kedua pertanyaan tersebut diuraikan sebagai berikut:

1. Peningkatan Kemampuan Pemecahan Masalah Matematika Terbuka Mahasiswa

Berdasarkan dari kemampuan yang dicapai siswa saat tes awal seperti telah diuraikan pada bagian pendahuluan, yaitu sebanyak 93,33\% (28 orang) dikatakan kurang mampu menyelesaikan masalah matematika terbuka yang berarti kemampuan siswa dalam memecahkan masalah matematika terbuka masih tergolong rendah. Hal ini disebabkan karena dalam pembelajaran matematika selama ini mereka tidak pernah dihadapkan pada masalah matematika terbuka. Mahasiswa tampak kebingungan dalam menjawab soal, karena ada soal yang tidak semua data dikemukakan secara eksplisit. Untuk meningkatkan kompetensi berpikir aktif, kreatif dan produktivitas mahasiswa, dosen haruslah memberikan kesempatan kepada mahasiswa yang mengarah ke hal tersebut. Salah satu cara adalah dengan pemecahan masalah matematika terbuka. Dalam pemecahan masalah ini siswa dituntut untuk memiliki wawasan berkaitan dengan pengalamannya dalam kehidupan nyata. Berarti, mahasiswa harus aktif mencari informasi dan belajar dari lingkungannya.

Setelah tindakan dalam dua siklus dengan menerapkan pendektan investigasi, kemampuan mahasiswa memecahkan masalah matematika terbuka cenderung meningkat dibandingkan sebelum tindakan. Pada siklus 1, rerata persentase skor siswa 54\% dan 17 orang $(56,66 \%)$ mahasiswa sudah mampu mencapai kategori minimal cukup baik, yaitu mendapat skor di atas 55\%. Jawaban yang dibuat mahasiswa cukup bervariasi, sesuai dengan hakikat masalah yang terbuka. Hal ini tentu terjadi karena adanya kesempatan bagi mahasiswa untuk mengembangkan kreativitas berpikirnya melalui pemecahan masalah matematika terbuka. Kesempatan yang sama lebih diintensifkan pada siklus 2, karena peningkatan yang terjadi di siklus 1 belum optimal. Dari hasil tes akhir siklus 2 terjadi peningkatan. Rerata persentase skor mahasiswa adalah 60\% dan sebanyak 25 orang mahasiswa $(83,33 \%)$ mampu mencapai kategori minimal cukup baik. Di samping itu, jawaban mahasiswa yang satu dengan yang lainnya tampak semakin bervariasi.

Dengan memperhatikan karakteristik pembelajaran dengan pendekatan investigasi matematika yang diterapkan dalam penelitian ini, adalah suatu hal yang wajar bahwa pendekatan pembelajaran ini mampu meningkatkan kemampuan pemecahan masalah matematika terbuka siswa. Secara teoritis pembelajaran dengan pendekatan investigasi matematika memiliki beberapa keunggulan, yang apabila keunggulan-keunggulan ini 
mampu dimaksimalkan dalam kegiatan belajar mengajar di kelas akan mampu meningkatkan kemampuan pemecahan masalah matematika terbuka mahasiswa. Keunggulan dari pendekatan investigasi matematika secara pribadi yaitu dalam proses pembelajaran mahasiswa dapat bekerja secara bebas, dapat belajar untuk memecahkan dan menangani suatu masalah. Secara sosial, keunggulan investigasi yaitu meningkatkan belajar bekerja sama, belajar berkomunikasi baik dengan teman sendiri maupun dengan dsoen dan belajar menghargai pendapat orang lain. Secara akademis, mahasiswa terlatih untuk mempertanggung jawabakan jawaban yang diberikannya, dan mencek kebenaran dari jawaban yang mereka buat.

Pada pelaksanaannya, pembelajaran diawali dengan diberikan masalah yang dapat dibayangkan atau terjangkau oleh pikiran mahasiswa. Masalah yang diberikan berkaitan dengan situasi dalam kehidupan sehari-hari mahasiswa. Pemilihan pemberian masalah kepada siswa dimaksud untuk melihat sejauh mana siswa dapat menginterprestasikan soal berdasarkan pengertiannya dan membuat suatu kesimpulan tentang apa yang harus dikerjakannya. Hal ini sesuai dengan karakteristik pertama dari pendekatan investigasi matematika yaitu membaca, menerjemahkan dan memahami masalah.

Pelaksanan pembelajaran yang diawali dengan masalah mampu memberikan rangsangan kepada mahasiswa untuk memahami masalah, selanjutnya mahasiswa mulai mencoba-coba ide mereka sendiri untuk meyelesaikan masalah tersebut dan memilih cara/strategi untuk menyelesaikan masalah. Hal ini sejalan dengan karakteristik pembelajaran dengan pendekatan investigasi matematika yang kedua yaitu pemecahan masalah.

Selanjutnya, dalam proses pembelajaran mahasiswa akan mempresentasikan hasil penyelesaian masalah yang diperoleh. Sehingga mahasiswa lain dapat memperhatikan jawaban yang dikomunikasikan secara individi maupun kelompok. Proses inilah yang membantu peningkatan kemampuan pemecahan masalah matematika terbuka mahasiswa.

2. Peningkatan Aktivitas Mahasiswa

Variasi jawaban mahasiswa mencirikan bahwa masalah matematika terbuka memiliki banyak cara menjawab dan banyak jawaban, namun secara matematis adalah benar. Hal ini merupakan kesempatan bagi mahasiswa melakukan "experience in finding something new in the process" (Schoenfeld, 1997 dalam Sudiarta, 2003) dalam rangka latihan berpikir aktif, kreatif dan produktif. Pemecahan masalah matematika terbuka memerlukan kemampuan berpikir kreatif yang lebih tinggi dibandingkan dengan pemecahan masalah matematika tertutup. Karena itu, tampak wajar pada siklus II pertemuan pertama kadar aktivitasnya mahasiswa masih mencapai kategori kurang baik yang berarti belum mencapai kategori cukup baik. Namun dilihat dari rerata persentase skor pada siklus II secara keseluruhaan, kadar aktivitas siswa sudah mencapai 80\%. Dengan demikian, hasil analisis data aktivitas mahasiswa pada siklus I dan siklus II diperoleh kesimpulan bahwa aktivitas mahasiswa dalam pembelajaran adalah meningkat sebesar 21 $\%$.

Hasil penelitian ini sejalan dengan penelitian Japa (2008) yang dalam penelitiannya menyimpulkan bahwa dengan penerapan investigasi matematika, cara belajar siswa dapat ditingkatkan. Peningkatan cara belajar siswa tersebut dapat dilihat dari antusiasme dan kerjasamanya dalam belajar kelompok. Di samping itu, mahasiswa tampak aktif, kreatif, dan produktif dalam belajar. Dan kemampuan mahasiswa dalam pemecahan masalah matematika terbuka mengalami peningkatan.

Salah satu kendala utama mahasiswa dalam pemecahan masalah matematika terbuka adalah faktor bahasa. Hal tersebut dikatakan demikian, karena saat penelitian dilaksanakan, didapat mahasiswa memiliki ide dalam pikirannya, tetapi kurang terlatih menggunakan ide tersebut. Sehingga mahasiswa kurang dalam menentukan apa yang diketahui dan apa yang 
ditanya. Misalnya dari Lembar Aktivitas Mahasiswa 1 bagian masalah 1, pada fase memahami masalah. Dosen bertanya " apakah yang diketahui dari masalah yang pertama ini?" Mendengar pertanyaan ini mahasiswa dengan nomor urut empat kembali bertanya " manakah cerita yang dimaksud disini bu?" kemudian dosen mengarahkan untuk melihat kalimat yang ada pada lingkaran. Selanjutnya secara spontan mahasiswa no urut empat menjawab:'oh...yang diketahui adalah rudi memiliki 5 lembar uang ribuan dan tina memiliki uang 3 lembar sepuluhan ribuan"

Hal ini juga sejalan dengan penelitian Japa (2008) yang menyatakan bahwa salah satu faktor yang dapat mempengaruhi kemampuan mahasiswa mengkonstruk pengetahuannya adalah "Bahasa". Selain itu, faktor bahasa dan pengalaman belajar berpengaruh pada pola meaning yang dibangun oleh siswa (Driver dalam Sutrisno, 1994). Jadi, sesungguhnya mahasiswa punya ide dalam pikirannya. Tetapi karena kurang terlatih menggunakan ide tersebut dengan bahasa yang benar, muncul berbagai kesulitan seperti dalam menentukan apa yang diketahui, apa yang ditanyakan, serta bagaimana hubungan ketentuan yang satu dengan yang lainnya. Kemampuan menentukan hubungan ketentuan satu dengan yang lainnya itu, akan mengarahkan pikiran mahasiswa dalam menentukan jenis operasi yang diperlukan dalam pemecahan masalah.

\section{KESIMPULAN}

Berdasarkan temuan dan hasil analisis data penelitian, dikemukakan beberapa simpulan sebagai berikut:

1. Pendekatan investigasi matematika dapat meningkatkan kemampuan pemecahan masalah matematika untuk mahasiswa prodi pendidikan matematika FKIP UMSU. Hal ini diketahui dari rata-rata nilai kemampuan pemecahan masalah matematika mahasiswa pada siklus I adalah 10,73 meningkat menjadi rata-rata 12 pada siklus II. Persentase mahasiswa yang telah mampu memecahkan masalah pada siklus I adalah $56,66 \%$ meningkat menjadi $83,33 \%$ pada siklus II.

2. Pendekatan investigasi matematika dapat meningkatkan kadar aktivitas mahasiswa bagi mahasiswa prodi pendidikan matematika FKIP UMSU. Hal ini dapat dilihat dari hasil skor rerata atau persentase mahasiswa dalam kegiatan tindakan siklus I dan siklus II yang relatif menunjukkan adanya kenaikan. Persentase rerata skor pada kadar aktivitas mahasiswa siklus I adalah 59\% meningkat menjadi 80\% pada siklus II.

\section{DAFTAR PUSTAKA}

Batubara, I. H. 2017. Peningkatan Kemampuan Berpikir Kritis Matematis Melalui Model Pembelajaran Berbasis Masalah Berbantuan Autograph Dan Geogebra Di SMA Freemethodist Medan. Kumpulan Jurnal Dosen Universitas Muhammadiyah Sumatera Utara. V(6), 97-104.

- 2017. Peningkatan Kemampuan Pemahaman Konsep Matematis Melalui Model Pembelajaran Berbasis Masalah Berbantuan Autograph Dan Geogebra Di Sma Freemethodist Medan. Journal of Mathematics Education and Science. 3(2), $47-$ 54.

Japa, I G. N. (2008). Peningkatan Kemampuan Pemecahan Masalah Matematika Terbuka melalui Investigasi bagi Siswa Kelas V SD 4 Kaliuntu. Jurnal Penelitian dan Pengembangan Pendidikan. Lembaga Penelitian Undiksha.

Masrinawatie. 1999. Upaya meningkatkan pemahaman konsep pengukuran luas siswa kelas V SD negeri Sumbersari III Kotamadya Malang dengan investigasi matematika. Tesis. PPS IKIP Malang.

NCTM. (2000). Principle and Standards for School Mathematic. Virginia: NCTM. 
Sudiarta, G. P. 2003. Pembangunan konsep matematika melalui Open-ended problem: Studi kasus pada sekolah dasar Elisabeth Osnabrueck Jerman. Jurnal Pendidikan dan Pengajaran. IKIP Negeri Singaraja: Edisi Oktober 2003.

TIM Penulis. 2001. Strategi Pembelajaran Matematika Kontemporer. Jurusan Pendidikan Matematika. Fakultas Pendidikan Matematika dan Ilmu Pengetahuan Alam. Universitas Pendidikan Indonesia.

Tim Pelatih Proyek PGSM. 1999. Penelitian Tindakan Kelas (Classroom Action Research). Depertemen Pendidikan dan Kebudayaan Direktorat Jenderal pendidikan Tinggi Proyek Pengembangan Guru Sekolah Menengah (Secondary School Teacher Development Project). Jakarta.

Turmudi (2008). Landasan Filsafat dan Teori Pembelajaran Matematika: Paradigma Eksploratf dan Investigatif. Jakarta: Leuser Cita Pustaka. 